\title{
Effect of diazepam and hyoscine butylbromide on response to secretin and cholecystokinin-pancreozymin in man
}

\author{
J. H. B. SAUNDERS, GUYA MASOERO, AND K. G. WORMSLEY 1 \\ From the Department of Therapeutics, University of Dundee, Dundee
}

SUMMARY Ten subjects received secretin and cholecystokinin or, in duplicate tests, the two hormones together with either diazepam or diazepam plus hyoscine butylbromide in order to determine whether these drugs, which are often used during retrograde endoscopic cannulation of the pancreatic duct, affect pancreatic and biliary secretion in response to the hormones. Diazepam with hyoscine butylbromide reduced the secretion of trypsin into the duodenum and delayed the appearance of both trypsin and bilirubin in duodenal aspirate. These effects must be taken into account when interpreting pancreatic and biliary responses measured during direct cannulation of the pancreatic duct.

Endoscopic retrograde cannulation of the pancreatic duct has recently been used to measure pancreatic function by collecting the pancreatic juice directly from the pancreatic duct during stimulation with exogenous hormones (Cotton et al., 1974; Gregg et al., 1975; Robberecht et al., 1975). Since sedatives such as diazepam and anticholinergic drugs such as hyoscine butylbromide (Buscopan) are often used during the introduction of the endoscope and ampullary catheter and since anticholinergic drugs have been shown to inhibit the pancreatic secretory response to exogeneous stimulant hormones such as secretin and cholecystokinin-pancreozymin (CCK) (Dreiling and Janowitz, 1960; Elmslie et al., 1964; Bock et al., 1968; Schapiro et al., 1968), we have assessed the effect of these drugs on the pancreatic and biliary responses to parenteral secretin plus cholecystokinin.

\section{Methods}

Ten patients undergoing study for suspected pancreatic disease underwent duplicate tests, in random order, after obtaining informed consent. Each individual was intubated with a double lumen tube with air vents, under radiological control, so that the duodenal aspiration holes were sited in the descending duodenum and the gastric aspiration

${ }^{1}$ Address for communications: KGW, Ninewells Hospital, Dundee DD2 1UB.

Received for publication 12 January 1975 vents in the antrum. Secretin (1 clinical unit/kg-h) and cholecystokinin-pancreozymin (1 Ivy unit/ $\mathrm{kg}-\mathrm{h}$ ) were administered for 45 minutes by continuous intravenous infusion in $0.15 \mathrm{~mol} / 1$ sodium chloride. The hormones had been purchased from the GIH Laboratory, Karolinska Institute, Stockholm, Sweden. On a different day, five subjects received $10 \mathrm{mg}$ diazepam while the other five patients were given $10 \mathrm{mg}$ diazepam plus $20 \mathrm{mg}$ hyoscine butylbromide by intravenous injection immediately before the start of the infusion of hormones. Duodenal aspirate was collected in 15 minute batches and volume recorded. The concentration of bicarbonate was measured by adding a known excess of acid, boiling and backtitrating the residual acid with $0 \cdot 1 \mathrm{~mol} / 1$ sodium hydroxide to $\mathrm{pH} 7$. Tryptic activity was measured photometrically, using benzoyl-argininep-nitroanilide as substrate. Bilirubin concentration is expressed in terms of icteric index.

\section{Results}

Diazepam alone did not significantly affect the total output of bicarbonate, trypsin or bilirubin in response to the hormones (Fig. 1).

Addition of hyoscine butylbromide did not significantly affect the output of bicarbonate but the outputs of trypsin decreased in every subject (Fig. 2). There was a significant delay in attaining peak rates of secretion of trypsin and of bilirubin compared with control after the injection of diazepam plus hyoscine butylbromide during both the 

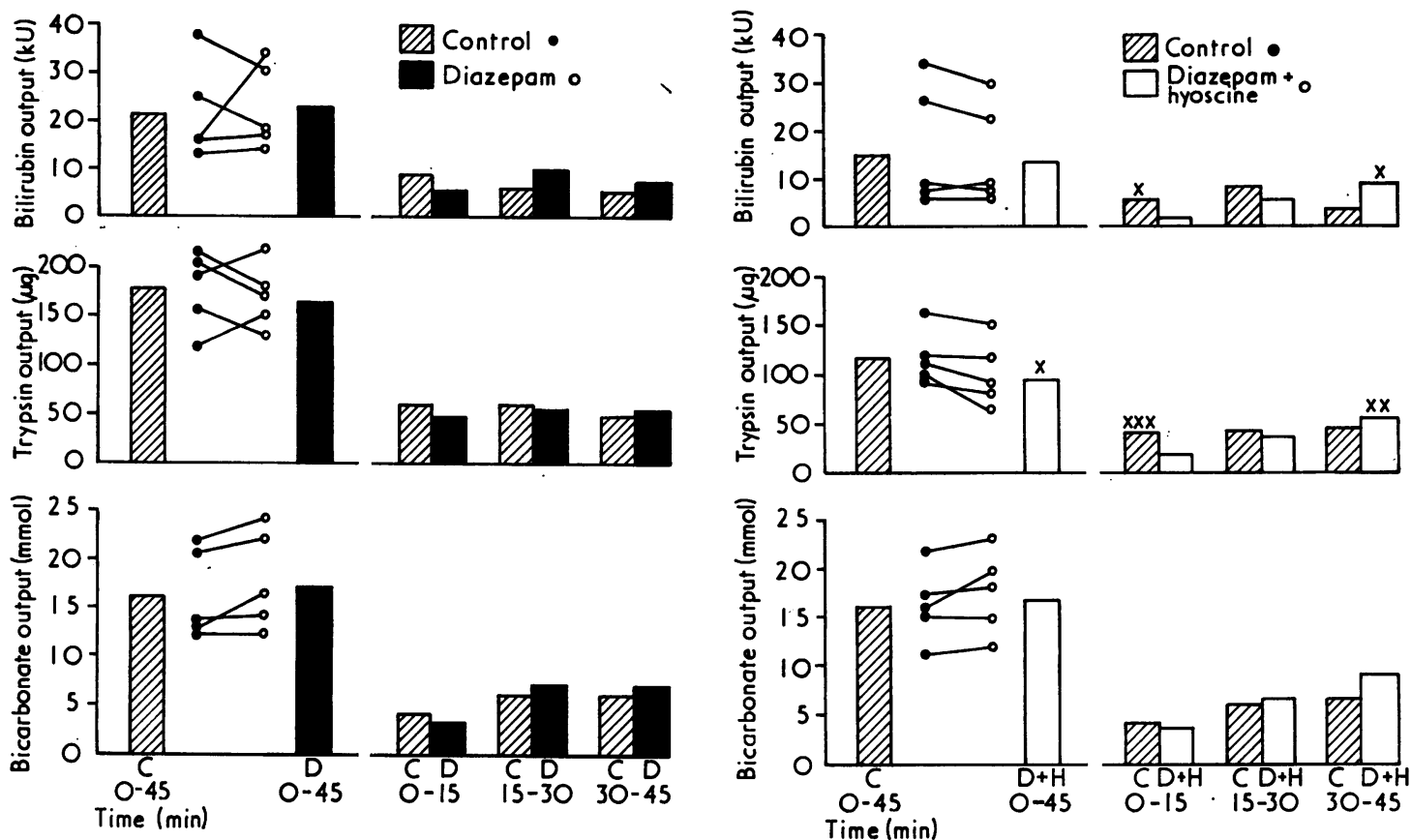

Fig. 1 Pancreatic and biliary responses to secretin and cholecystokinin-pancreozymin without and with diazepam. Each pair of points represents results from one individual. $C=$ control $; D=$ with diazepam. The vertical bars indicate mean values of control or diazepam tests. The ordinate represents secretory values during the 45 minute tests. The pairs of columns on the right of the figure indicate the appropriate outputs (control and with diazepam, respectively) during the three successive 15 minute collection periods.

first 15 (Fig. 2) and the first 30 minutes (P $<0.005$ for trypsin and $<0.05$ for bile pigment) after start of stimulation with the continuous infusion of exogenous hormones.

\section{Discussion}

The results of the present study indicate that intravenous diazepam or diazepam plus hyoscine butylbromide do not appreciably alter the bicarbonatesecretory response to exogenous hormones in the doses used in the present study. However, as noted previously (Dreiling and Janowitz, 1960; Elmslie et al., 1964; Bock et al., 1968; Schapiro et al., 1968), the administration of an anticholinergic reduced the total output of trypsin in response to the exogenous hormones, albeit only slightly in the dose used. More important, the combination of the diazepam and hyoscine butylbromide significantly de-

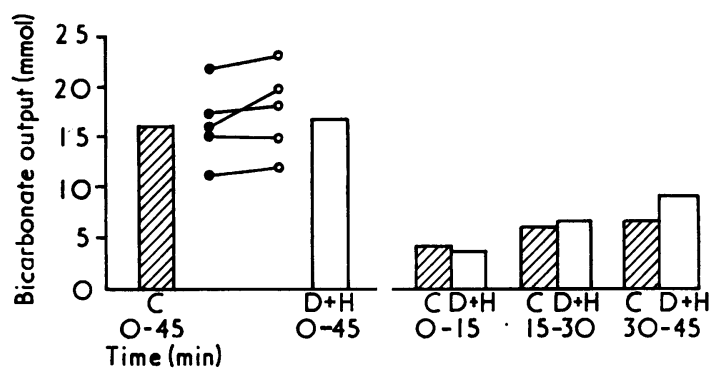

Fig. 2 Pancreatic and biliary responses to secretin and cholecystokinin-pancreozymin without and with diazepam plus hyoscine butylbromide.

Significance of symbols as in Fig. 1. $\times$ Significant difference between the values represented by the pair of columns of $\mathrm{P}<0.05, \times \times \mathrm{P}<0.02, \times \times \times \mathrm{P}<0.01$.

layed, for 30 minutes, both the secretion of enzymes and cholecystokinesis in response to the exogenous hormones. The use of these drugs during endoscopic cannulation of the pancreas will therefore not significantly affect measurement of pancreatic secretory capacity, provided that the collection is carried out for a sufficiently long period to compensate for lag in the secretory response.

K.G.W. gratefully acknowledges a research grant from the Wellcome Foundation. The technical assistance of Mrs F. Dear and Miss S. Drummond is gratefully acknowledged.

\section{References}

Bock, O. A. A., Bank, S., Marks, I. N., Moshal, M. G., Groll, A., Loxton, A., and Dines, M. (1968). Effect of propantheline bromide and pipenzolate bromide upon exocrine pancreatic secretion. Gastroenterology, 55, 199-203.

Cotton, P. B., Cremer, M.. Robberecht, P., and Christophe.J. (1974). Biochemical studies of pure pancreatic juice obtained by duodenoscopic cannulation of the pancreatic duct in conscious patients. Gut, 15, 838 .

Dreiling, D. A., and Janowitz, H. D. (1960). Inhibitory effect 
of new anticholinergics on the basal and secretin-stimulated pancreatic secretion in patients with and without pancreatic disease. American Journal of Digestive Diseases, 5, 639-654.

Elmslie, R. G., White, T. T., and Magee, D. F. (1964). Observation on pancreatic function in eight patients with controlled pancreatic fistulas. Annals of Surgery, 160, 937-949.

Gregg, J., Sipos, T., Sharma, M., Gibbons, G., Whalen, M., and Blackburn, G. (1975). Enzymatic analysis of pure pancreatic juice obtained during the endoscopic cannulation of the main pancreatic duct. Gastroenterologv 68, 904.
Robberecht, P., Cremer, M., Vandermers, A., VandermersPiret, M.-C., Cotton, P., de Neef, P., and Christophe, J. (1975). Pancreatic secretion of total protein and of three hydrolases collected in healthy subjects via duodenoscopic cannulation. Effects of secretin, pancreozymin and caerulein. Gastroenterology, 69, 374-379.

Schapiro, H., Wruble. L. D., Estes, J. W., Sherman, R., and Britt, L. G. (1968). Anticholinergic drug action on pancreatic exocrine outflow in man and dog. American Journal of Digestive Diseases, 13, 608-614.

\section{The April 1976 Issue}

\section{THE APRIL 1976 ISSUE CONTAINS THE FOLLOWING PAPERS}

Alcohol and absorption from the small intestine 1. Impairment of absorption from the small intestine in alcoholics N. KRASNER, K. M. COCHRAN, R. I. RUSSELL, H. A. CARMICHAEL, AND G. G. THOMPSON

Alcohol and absorption from the the small intestine 2. Effect of ethanol on ATP and ATPase activities in guinea-pig jejunum N. KRASNER, H. A. CARMICHAEL, R. I. RUSSELL, G. G. THOMPSON, AND K. M. COCHRAN

Impairment of jejunal absorption rate of carnosine by glycylglycine in man in vivo G. C. COOK

Fibreoptic endoscopy and the use of the Sengstaken tube in acute gastrointestinal haemorrhage in patients with portal hypertension and varices B. $\mathrm{H}$. NOVIS, P. DUYS, G. O. BARBEZAT, J. CLAIN, S. BANK, AND J. TERBLANCHE

Improved technique for placement of intestinal feeding tube with the fibreoptic endoscope R. S. K. CHUNG AND L. DENBESTEN

Endoscopic pancreatography in evaluating results of pancreatico-jejunostomy CH. KUGELBERG, L. WEHLIN, B. ARNESJÖ, AND U. TYLÉN

Continuous monitoring of the effect of pentagastrin on gastric emptying of solid food in man s. G. HAMILTON, H. J. SHEINER, AND M. F. QUINLAN
Induction of pyloric hypertrophy by pentagastrin J. A. DODGE AND A. A. KARIM

Successful treatment of a malignant gastrinoma with streptozotocin J. R. HAYES, N. O'CONNELL, T. O'NEILL, J. J. FENNELLY, AND D. G. WEIR

Determination of liver volume by the use of a gamma camera connected with 1600 or 4096 channel analyser in diffuse liver diseases M. FUII. T. MUKAI, T. YAMAMOTO, AND G. WAKISAKA

Relationship between bile acid malabsorption and pancreatic insufficiency in cystic fibrosis A. M. WEBER, C. C. ROY, L. CHARTRAND, G. LEPAGE, O. L. DUFOUR, C. L. MORIN, AND R. LASALLE

Serum lysozyme levels in Crohn's disease and ulcerative colitis T. L. PEETERS, G. VANTRAPPEN, AND K. GEBOES

Influence of autonomic nerves on the internal anal sphincter in man B. FRENCKNER AND T. IHRE

Progress report Cytotoxic therapy for gastrointestinal carcinoma T. J. PRIESTMAN

Notes on books

Notes and activities

Copies are still available and may be obtained from the PUBLISHING MANAGER, BRITISH MEDICAL ASSOCIATION, TAVISTOCK SQUARE, LONDON, WC1H 9JR, price $£ 2.00$, including postage 